\title{
Financial Inclusion and Economic Growth in Nigeria: An Empirical Study
}

\author{
Okonkwo Jisike J. and Nwanna Ifeanyi O. \\ Nnamdi Azikiwe University Awka, Nigeria
}

\begin{abstract}
The study investigates the effects of financial inclusion on economic growth in Nigeria from 1992 to 2018. Selected variables for financial inclusion include; currency outside banking, currency in circulation, microfinance banks' deposits, number of commercial bank branches, commercial banks' credit to private sector, loans and deposits of rural branches of commercial banks. On the other hand, nominal GDP was the selected measure of economic growth. The research design used is the ex-post facto. The study examined the relationship between the variables using regression and then examined the effects using the Grander Causality test. The results of the test revealed that currency in circulation has an insignificantly positive relationship as well as a causal effect on economic growth in Nigeria. Likewise, loans extended by rural branches of commercial banks also have a positive and significant relationship and causal effect on economic growth in Nigeria. Deposits of rural branches of commercial banks have causal effect on GDP in Nigeria and a positive relationship though not significant. The study recommends that the government and monetary authorities should ensure the promotion of banking service and the establishment of bank branches deeper in the rural areas and equally support these banks to meet the demands of these areas efficiently.
\end{abstract}

Key Words: Financial Inclusion, Economic Growth, Sustainable Banking Principles, unbanked and non-formal banking sectors

\section{INTRODUCTION}

$\mathrm{T}$ he standard of financial inclusion is anticipated to spur the economy into higher indices of growth and development through making funds available (and creating access) for investment and economic purposes where they are non-existent. Harnessing and accumulating these resources provides a huge source of cheap long-term investable capital (Kama and Adigun 2013). It involves the bringing together of the informal financial world into the stream of affairs. Nwafor and Yomi, (2018) stressed that generally, the low and middle income earners make up the largest percentage of the populace and therefore controls a huge portion of the economy's idle fund; though, held in small volumes in the hands of each of the several million members of this group therefore, harnessing and accruing these resources offers a huge basis of cheap long-term investable capital. Most economies that have not embraced financial inclusion properly are mostly structured that a lot of funds flow in the informal sector which is detrimental to society and the individual (Gazdar and Cherif, 2014, Kazeem, 2017). As far as the individual is concerned, absence of financial inclusion forces the unbanked into non-formal banking sectors characterized by high interest rates and small amount of available funds.

Financial sector development makes two mutually reinforcing contributions to poverty reduction. This is through its impact in accelerating economic growth and direct benefits to the poor. In order to measure financial inclusion, the level of access to financial services has to be measured (Yorulmaz, 2016). Zulkhibri and Ghazal (2017) supported that many studies in economic development and poverty reduction suggest that financial inclusion matters. For instance, empirical evidence suggests that improved access to finance is not only pro-growth and reduces income inequality and poverty. Evidence shows that appropriate financial services can help improve household welfare and spur small enterprise activity (Yorulmaz 2016, Eton, Uwonda, Mwosi, Barigye, and Ogwel 2019). There is also macroeconomic evidence to demonstrate that economies with deeper financial intermediation tend to grow faster and reduce income inequality. This lends credence to the importance of institutions in the process of financial intermediation (Kazeem, 2017). The goals of financial inclusion can be met largely by initiative of banking sector to cut across various strata of society, regions, gender and income and encourage the public to embrace banking habit (Akhil, 2016 and Wokabi and Fatoki 2019). There is therefore the need to act swiftly and collaboratively in pursuit of financial inclusion objectives in Nigeria. Through financial inclusion more people will involve in the formal financial system by having more of the currency in circulation in the banking system, provision of more credit for productive purposes, and ultimately enhancing GDP growth. Economic growth is an objective of financial inclusion which includes political, economic and social inclusion (Nalini and Mariappan, 2012) as cited by Aina and Oluyombo (2014).

The five-year strategy (2019-2024) plan of the Central Bank is ultimately to ensure that a 95 per cent financial inclusion rate is achieved by 2024. The introduction of the N50 charge would discourage more people from using mobile banking and thus defeat its purpose. If you want to retain your customers, you cannot afford to add such money. These developments have triggered very aggressive changes in the financial services industry, introducing significant dynamism into the industry's value chain - changing mode the production, delivery and consumption of financial products and services, the regulators that is the Central Bank of Nigeria $(\mathrm{CBN})$ has been at the forefront of entrenching in the 
Nigerian banking industry through the implementation of the Nigerian Sustainable Banking Principles (NSBP), which has formally been adopted by the $\mathrm{CBN}$ and 33 banks, discount houses and Development Finance Institutions.

According to Akhil (2016), financial inclusion is defined as delivery of financial services to the poor at affordable cost while El Said, Emara, and Pearlman (2020) posit that Financial inclusion means access to, and use of, financial products and services by households or firms which is one of the main, albeit challenging priorities in Emerging Markets (EMs), and a key factor for financial development. Financial inclusion, development and economic growth are interwoven and interconnected. Zulkhibri and Ghazal (2017) reported that financial inclusion (FI), within the broader context of inclusive development, is viewed as an important means to tackle poverty and inequality and to address sustainable development goals (SDGs). Abbas and Atanda (2019) buttressed by suggesting that the strength of scholarly submissions lies in the fact that financial inclusion is in fact, very imperative for the growth process of any economy including Nigeria because as more individuals are brought or captured into the formal financial system, it will help ensure proper planning and decision making by policy makers. According to the Nigerian Financial Inclusion Strategy (NFIS 2018), financial inclusion is achieved when adult Nigerians have easy access to a broad range of formal financial services that meet their needs and are provided at an affordable cost. This definition includes the following elements: Ease of access to financial products and services; Use of a broad range of financial products and services; Financial products designed according to need; Financial services should be affordable even for low-income groups. Abbas and Atanda (2019) stated that a review of most scholarly submissions high-light the fact that the purpose of financial inclusion is to improve economic growth by increasing the economic wellbeing of people at the base of the pyramid and unbanked by availing them affordable financial services at a reasonable cost.

\section{LITERATURE REVIEW}

This work is hinged on the systems theory of financial inclusion which posits that financial inclusion results are realized through sub-sets including economic or financial and social system which financial inclusion depend on, and consequently, more financial inclusion will have positive effects for the structure. A symbolic difference in a sub-set of the structure can significantly affect the predicted financial inclusion outcome. An epitome is instituting restrictions on economic agents and suppliers of financial services that is a sub-set of the system may adjust their interest with that of the users of primary financial services, and can enforce and instigate economic agents and suppliers of financial services to offer modest and quality economical financial services to end users in the context of specified rules that preserve consumers of financial services from unnecessary segregation and profiteering.

\section{Financial Inclusion in Nigeria}

Some concerns are accountable for not having realized optimal financial inclusion which include among others; low awareness, the reach of these mobile money products and lack of trust. Nguling'wa (2019) opined that notwithstanding the bright outlook of financial inclusion derived from financial technology adoption, several challenges still ringer. These include limited outreach of the brick and mortar model, especially in rural areas, high and sticky levels of financial illiteracy, high lending rates leading to significant spread between lending and deposit rates, and low saving and poor loan repayment culture. Responsiveness to the numerous means of financial inclusion remains a means of achieving such task. Before the advent of digital banking, financial exclusion has manifested prominently in Nigeria with the bulk of the money in the economy staying outside the banking system. The subject of financial exclusion has therefore been a major economic test that has received the consideration of the various governments over the past eras. The World bank (2015) explained that policy and research initiatives must then focus on involuntary exclusion as it can be addressed by appropriate economic programs and policies which can be designed to increase income levels, reduce poverty, bridge income inequality gap and correct market failures and imperfections. Previously, the Nigerian economy was predominantly a cash-based economy with significant proportion of the narrow money stock in the form of currency outside the banking system. Although the average ratio of the currency outside the banking sector (COBs) to narrow money supply (M) trended downward from 61.1 per cent 1 in the 1960 s to 44.3 per cent in the 1970 s and later to 40.9 per cent in the 1980s, the value, in nominal terms, was still high considering the growth in the level of narrow money in the economy. The decline in the ratio was attributable to a combination of developments, including increased literacy and government policies directed at encouraging financial sector growth. The CBN, during this period, initiated rural banking programme directing banks to open branches in the rural areas, encouraging Nigerians to use financial institutions and products more. The crisis in the banking industry during the 1990s eroded the confidence of the populace in the industry. The problem was aggravated by the excessive spending of the political class leading to the increase in the level of currency outside the banking system. The ratio of currency outside the banking system moved up to 47.7 per cent by end of the 1990s.

The stirred use of the financial services declined the ratio of currency in the informal sector to 38.2 per cent by the end of 2005. In a cross-country comparative analysis of the financial exclusion rate using the same measure of the ratio of the currency outside the banking system to narrow money supply, Martin Oluba (2008), compared the financial exclusion levels in Switzerland, USA, Venezuela, Nigeria, Pakistan, India and Argentina in four and half decades (1960 - 2005), although each country with a different objective. The goal of financial 
inclusion seems to vary from country to country and several commitments and policies have been in difficult form for implementation (Anyanwu, Ananwude and Nnoje, 2018). He found that Nigeria had not really done badly in comparative terms even though there was need to accelerate the exclusion rate reduction. Omojolaibi (2017) posit that in 2012, Nigeria introduced the National Financial Inclusion Strategy (NFIS) and promoted it as a key driver in becoming one of the world's largest economies. The goal of NFIS is to decrease the number of Nigerians without access to financial services from $46.3 \%$ to $20 \%$ by the year 2020 .

In Nigeria, the population that has access to financial services increased from $36.3 \%$ in 2010 to $43 \%$ in 2012, $48.6 \%$ in 2014 and remained at that level in 2016 while the banking public increased from $30 \%$ in 2010 to $32.5 \%, 36 \%$ and $38.3 \%$ in 2012, 2014 and 2016 respectively. The formal other including the microfinance banks, insurance companies, pension funds and similar service providers grew between 2010 (6.3\%) and 2016 (10.3\%). The informal sector (Non-Governmental Organizations (NGOs) and financial cooperatives) declined from $17.4 \%$ in 2010 to $9.8 \%$ in 2016.

The main aim of the study is to examine the effect of financial inclusion on economic growth in Nigeria. The study therefore decomposed financial inclusion and examined the effects of number of commercial banks' branches, currency in circulation, currency outside banks, commercial banks' credit to private sector, loans and deposits of rural branches of commercial banks on economic growth in Nigeria.

\section{Empirical Review}

Nwafor and Yomi (2018) studied the relationship between financial inclusion and economic growth in Nigeria. Two hypotheses were formulated, corresponding data (spanning from 2001 to 2016) were obtained and tested using Twostaged Least Squares Regression Method. Findings revealed that financial inclusion have significant impact on economic growth in Nigeria and that financial industry intermediation have not influenced financial inclusion within the period under review. It was recommended that Nigerian banks should develop financial products to reach the financially excluded regions of the country as this will increase GDP per capital of Nigeria and consequently economic growth.

In a related study, Anyanwu, Ananwude and Nnoje, (2018) evaluated the effect of available microfinance banks' products in rural communities via rent savings, child education, new born and daily savings account on women empowerment. A descriptive survey design was utilized to realize our objective. Two hundred (200) questionnaires were distributed to respondents, out of which one hundred and ninety (190) were fully completed and used for the analysis. The study recommended the creation of more women tailored products by microfinance banks. This will avail them the opportunity to choose from variety of products and services that specifically suit their needs. Furthermore, collateral for women to access finance from these microfinance banks should be community/socially based rather than individually based.

Olubanjo (2017) studied income, education, age, gender, urban-rural classification and access, as key drivers of financial inclusion and analysed their impact on the likelihood of being banked in Nigeria. The study used a survey of over 20,000 respondents in 37 states in Nigeria from 2008 to 2016. Being a woman, a youth and living in a rural area, however, have significant negative effects on financial inclusion. Lastly the lower the average travel time to the nearest branch of a bank, the more likely an individual will be financially included in Nigeria. The findings will inform policy interventions in areas such as financial literacy and poverty alleviation.

Aina and Oluyombo (2014) investigated the economy of financial inclusion in Nigeria. The study found that though access to bank accounts is high, a majority of the respondents operate savings accounts. However, bank account ownership penetration ratio of 1.4 accounts to an adult including inactive accounts is very low. The use of bank accounts in receiving money from, and sending money to family members living far away helps to service and maintain good family bond typical of Africans where family ties are held in high esteem. Most adults use their accounts between one and five times in a month but $24.01 \%$ of the accounts are inactive in receiving deposits while $6.91 \%$ are inactive for withdrawal in a month. The most popular non-cash payment methods are ATM/Debit card and wire transfer/on-line payment. 59.58\% of those who save used a bank account, $32.5 \%$ save with cooperative societies while $26.25 \%$ used daily contributors and rotational savings scheme.

Mbutor and Uba (2013) studied a simple model showing the impact of financial inclusion on monetary policy in Nigeria between 1980 and 2012. The result of the study supported the notion that growing financial inclusion would improve the effectiveness of monetary policy. However, the coefficient of the number of bank branches has the wrong sign and this is explained by the fact that, in opening branches, banks mainly pursue profits but not financial inclusion which is a policy objective, so that there are clusters of branches which are under-utilized while numerous locations which are considered not favourable for balance sheets are under-branched.

\section{EMPIRICAL METHODOLOGY}

The research design used is the ex-post facto so as to ensure the data is not altered. To empirically verify the impact of financial inclusion on economic growth, regression method analytical technique was employed following the quantitative nature of the data. Simple regression equation was employed following one dependent and independent variables. Also, secondary data from Bank reports and statistical bulletins was used. In achieving the objective of this study, an estimation of a modified linear regression model was followed. Consistent with the literature discussion, the financial inclusion model may be specified as follows: 
NGDPit $=\alpha 0+\alpha$ FININC $+\beta \Sigma C$ Vit

Where: NGDP is Nominal Gross Domestic Product, FININC is financial inclusion and $\Sigma$ CVit is a vector of control variables. Financial inclusion is proxied by the commercial bank branches (CBB), currency in circulation(CIC), Currency outside banking(COB), Credit to Private sector(CPS), microfinance banks' deposits, Rural branch deposit and(RBD) and Rural branch loan(RBL). The final equation which is stated in logarithm form so as to have a normal distribution may be written as follows.

\section{NGDP $i t=\alpha 0+\alpha \mathrm{CBB} i t+\alpha 2 \mathrm{CICit}+\alpha 3 \mathrm{COB} i t+\alpha 4 \mathrm{CPS} i t+\alpha i t+\alpha$ 5RBDit $+\alpha 6 \mathrm{RBL} i t+\alpha$ \\ 7MFBDeit.

\section{Data Presentation}

The data used in this study include currency outside banks (COB), currency in circulation (CIC), rural banks' depositors (RBD), rural banks' loans (RBL), banks' credit to private sector (CPS), number of Commercial banks' branches (CBB), Microfinance banks deposits (MFBD) and nominal gross domestic product (NGDP) from 1992 to 2018. The time series data are analyzed in three stages; firstly the pre-estimation test for stationarity of the data using the Augmented Dickey Fuller (ADF) unit root test, secondly, the ordinary least square regression to examine the relationship between economic growth and the selected financial inclusion variables, the Harvey's Heteroskedasticity test and finally the Grander Causality test to establish the causal relationship between the variables.

\section{ADF Unit Root Test for Stationarity}

The summary of the ADF unit root test results shown in table highlights the order of integration for each variable.

Summary of ADF Unit Root Test

\begin{tabular}{|c|c|c|c|c|c|}
\hline Variable & $\begin{array}{c}\mathrm{ADF} \\
\text { statistic }\end{array}$ & $\begin{array}{c}\text { Critical } \\
\text { Value } \\
(5 \%)\end{array}$ & $\begin{array}{l}\text { Number } \\
\text { of lags }\end{array}$ & $\begin{array}{c}\text { Order of } \\
\text { Integration }\end{array}$ & $\begin{array}{c}\text { Differenced } \\
\text { Variable }\end{array}$ \\
\hline NGDP & $\begin{array}{c}- \\
4.200321\end{array}$ & $\begin{array}{c}- \\
3.004861\end{array}$ & 2 & $\mathrm{I}(2)$ & DDNGDP \\
\hline CBB & $\begin{array}{c}- \\
3.172289 \\
\end{array}$ & $\begin{array}{c}- \\
3.004861 \\
\end{array}$ & 2 & $\mathrm{I}(2)$ & DDCBB \\
\hline CIC & $\begin{array}{c}- \\
3.069672 \\
\end{array}$ & $\begin{array}{c}- \\
3.004861 \\
\end{array}$ & 2 & $\mathrm{I}(2)$ & DDCIC \\
\hline $\mathrm{COB}$ & 4.930705 & $\begin{array}{c}- \\
2.991878 \\
\end{array}$ & 2 & $\mathrm{I}(0)$ & $\mathrm{COB}$ \\
\hline CPS & $\begin{array}{c}- \\
5.920581\end{array}$ & $\begin{array}{c}- \\
3.004861\end{array}$ & 2 & $\mathrm{I}(2)$ & DDCPS \\
\hline RBD & 3.254757 & $\begin{array}{c}- \\
2.998064\end{array}$ & 2 & $\mathrm{I}(1)$ & DRBD \\
\hline RBL & $\begin{array}{c}- \\
4.520993\end{array}$ & $\begin{array}{c}- \\
3.004861\end{array}$ & 2 & $\mathrm{I}(2)$ & DDRBL \\
\hline MFBD & 3.735226 & $\begin{array}{c}- \\
2.991878\end{array}$ & 2 & $\mathrm{I}(0)$ & MFBD \\
\hline
\end{tabular}

Source: 10.0 ADF Test Output, 2020.

As shown, nominal GDP, number of commercial bank branches, currency in circulation and credit to the private sector are stationary at second difference; therefore they are
I(2) variables. Rural bank loans and depositors are both stationary at first differencing; therefore they are $\mathrm{I}(1)$ variables. Finally, currency outside banking is stationary at level therefore it is an I(1) variable. The data of the variables were differenced accordingly and used to run the ordinary least square regression.

\section{Ordinary Least Square (OLS) regression}

The ordinary least square regression was used to examine the relationship between financial inclusion variables and nominal GDP in Nigeria. The parameters for analysis of the results include the regression coefficients, probability values ( $p$ values), the $\mathrm{R}$-squared $\left(\mathrm{R}^{2}\right)$ and Adjusted $\mathrm{R}^{2}$, the F-statistic and the Durbin-Watson Statistic. Table 4.3 shows the OLS regression involving the differenced data of the variables.

\section{Ordinary least square Regression Result}

Dependent Variable: DDNGDP

Method: Least Squares

Date:03/12/20 Time:08:51

Sample (adjusted): 19942018

Included observations: 25 after adjustments

\begin{tabular}{ccccc}
\hline \hline Variable & Coefficient & Std. Error & t-Statistic & Prob. \\
\hline \hline DDCBB & -0.307630 & 0.999427 & -0.307806 & 0.7620 \\
DDCIC & 3.861459 & 4.387580 & 0.880089 & 0.3911 \\
DDCPS & 0.241921 & 0.366913 & 0.659342 & 0.5185 \\
DDRBL & 0.002212 & 0.000822 & 2.692548 & 0.0154 \\
DRBD & 0.004426 & 0.008566 & 0.516655 & 0.6121 \\
MFBD & -0.006199 & 0.008731 & -0.710045 & 0.4873 \\
COB & 0.089571 & 0.289244 & 0.309674 & 0.7606 \\
C & 455.1100 & 529.2620 & 0.859895 & 0.4018 \\
\hline \hline & & \multicolumn{3}{|l}{} \\
R-squared & 0.435803 & Mean dependent var & 411.7372 \\
Adjusted R-squared & 0.203487 & S.D. dependent var & 2002.897 \\
S.E. of regression & 1787.536 & Akaike info criterion & 18.06940 \\
Sum squared resid & 54319874 & Schwarz criterion & 18.45944 \\
Log likelihood & -217.8675 & Hannan-Quinn criter. & 18.17758 \\
F-statistic & 1.875906 & Durbin-Watson stat & 2.949643 \\
Prob(F-statistic) & 0.136984 & & \\
\hline \hline
\end{tabular}

Source: Eviews 10.0 Output Data, 2020.

\section{Regression Coefficients}

The regression results show that microfinance banks' deposits and commercial bank branches have negative relationship with economic growth in Nigeria. The regression coefficients reveal that every billion naira increase in the deposits of the microfinance banks has coincided with a decrease of \#6.199million in the economic growth of Nigeria. Likewise, unit increase in the number of commercial bank branches has culminated in a fall $\$ 307$.6million in the economic growth of Nigeria.

On the other hand, currency in circulation, currency outside banks, credit to private sector, rural bank deposits and rural 
bank loans have positive relationship with economic growth in Nigeria. The regression coefficients indicate that every billion naira increase in the currency in circulation has coincided with the increase of $\$ 3.861$ billion in Nigeria's GDP. Similarly, each billion naira increase in the value of credit granted by banks to the private sector has been met with N241.9million in the value of Nigeria's GDP. Furthermore, each billion naira increase in the currency outside banks have coincided with increase in Nigeria's nominal GDP by \#89.571million. Finally, each billion naira increase in the deposits of rural branches of commercial bank and their loans extended have culminated into \$4.426million and ¥2.212million increase in Nigeria's GDP.

\section{Probability Values}

The p-value of 0.0154, shown reveals that rural banks' loans have a significant relationship with nominal GDP in Nigeria as it is less than 0.05 . On the other hand, the other p-values which are greater than 0.05 indicate that currency in circulation, currency outside banking, commercial bank branches, microfinance banks' deposits, credit to private sector and deposits of rural branches of commercial banks all have insignificant relationships with NGDP in Nigeria.

\section{$R$-squared and Adjusted $R$-squared}

The R-squared value of 0.435803 shows that about $44 \%$ of the variations in the economic growth of Nigeria can be explained by the combined behaviors of commercial bank branches, currency in circulation, currency outside banking, microfinance banks' deposits, credit to private sector, deposits and loans of rural branches of commercial banks. The adjusted $R^{2}$ of 0.203487 shows an adjustment for the number of variables; indicating that the independent variables explain about $20 \%$ of the trends in Nigeria's GDP.m

\section{The F-statistic}

The F-statistic is 1.875906. The Probability F-statistic is 0.136984 which is greater than 0.05 . This result implies that the overall relationship between economic growth and the selected financial inclusion variables is insignificant.

\section{Durbin-Watson Test Statistic}

The number of regressors $(k)$ is 7 , and the sample size (n) after adjustment is 25 . From the Durbin-Watson table the lower and upper limits are 0.610 and 1.915 respectively. The DurbinWatson statistic obtained from the OLS regression output is 2.949643 which is above the upper limit of the tabulated Durbin-Watson value. This indicates the absence of Autocorrelation problems.

\section{Heteroskedasticity Test}

Harvey's heteroskedasticity test was conducted to examine if the variance of the variables are homoskedastic as this assures the reliability of the error terms and the t-statistic values. The result for the Harvey's heteroskedasticity test is shown in the table

\section{Harvey's Heteroskedasticity Test Result}

Heteroskedasticity Test: Harvey

\begin{tabular}{llll}
\hline \hline & & & \\
F-statistic & 0.668405 & Prob. F(7,17) & 0.6959 \\
Obs ${ }^{*}$-squared & 5.395628 & Prob. Chi-Square(7) & 0.6118 \\
Scaled explained SS & 4.623968 & Prob. Chi-Square(7) & 0.7057 \\
\hline \hline
\end{tabular}

Test Equation:

Dependent Variable: LRESID2

Method: Least Squares

Date:03/12/20 Time:09:34

Sample: 19942018

Included observations: 25

\begin{tabular}{crrrr}
\hline \hline Variable & Coefficient & Std. Error & t-Statistic & Prob. \\
\hline C & 12.88457 & 0.653867 & 19.70520 & 0.0000 \\
DDCBB & 0.000400 & 0.001235 & 0.324273 & 0.7497 \\
DDCIC & 0.005938 & 0.005421 & 1.095458 & 0.2886 \\
DDCPS & -0.000375 & 0.000453 & -0.827396 & 0.4195 \\
DDRBL & $-5.33 \mathrm{E}-07$ & $1.02 \mathrm{E}-06$ & -0.524663 & 0.6066 \\
DRBD & $7.69 \mathrm{E}-06$ & $1.06 \mathrm{E}-05$ & 0.726376 & 0.4775 \\
MFBD & $1.19 \mathrm{E}-05$ & $1.08 \mathrm{E}-05$ & 1.105256 & 0.2844 \\
COB & -0.000487 & 0.000357 & -1.363756 & 0.1904 \\
\hline \hline & & & & \\
R-squared & 0.215825 & Mean dependent var & 13.04472 \\
Adjusted R-squared & -0.107070 & S.D. dependent var & 2.098871 \\
S.E. of regression & 2.208377 & Akaike info criterion & 4.676731 \\
Sum squared resid & 82.90782 & Schwarz criterion & 5.066771 \\
Log likelihood & -50.45913 & Hannan-Quinn criter. & 4.784911 \\
F-statistic & 0.668405 & Durbin-Watson stat & 1.526312 \\
Prob(F-statistic) & 0.695899 & & & \\
\hline \hline
\end{tabular}

Source: Eviews 9.0 Output Data, 2020.

As shown in table 4.4 , the probability chi-square is greater than. Therefore, the hypothesis of heteroskedasticity is rejected. This implies that the standard errors, t-statistic and the p-values of the OLS regression are reliable and unbiased.

\section{Granger Causality Results for NGDP and CBB}

\section{Pairwise Granger Causality Tests}

Date:03/12/20 Time:08:51

Sample: 19922018

Lags: 3

\begin{tabular}{lcrc}
\hline \hline Null Hypothesis: & Obs & F-Statistic & Prob. \\
\hline \hline CBB does not Granger Cause NGDP & 24 & 1.79447 & 0.1864 \\
NGDP does not Granger Cause CBB & & 2.15766 & 0.1306 \\
\hline \hline
\end{tabular}

Source: Eviews 10.0 Output Data, 2020.

The p-values shown in table above are 0.1864 and 0.1306 which indicate an acceptance both the first and second null hypotheses. This implies that $\mathrm{CBB}$ does not Granger cause NGDP and NGDP does not Granger cause CBB, then there is 
no causal effect between CBB and NGDP. The p-value of the first hypothesis is 0.1864 which is greater than 0.05 . Therefore, the null hypothesis is accepted. Number of commercial bank branches has no effect on economic growth in Nigeria.

\section{Granger Causality Results for NGDP and CIC}

Pairwise Granger Causality Tests

Date: 03/12/20 Time: 08:52

Sample: 19922018

Lags: 3

\begin{tabular}{lccc}
\hline \hline Null Hypothesis: & Obs & F-Statistic & Prob. \\
\hline \hline CIC does not Granger Cause NGDP & \multirow{2}{*}{24} & 3.81283 & 0.0295 \\
NGDP does not Granger Cause CIC & & 1.00565 & 0.4144 \\
\hline \hline
\end{tabular}

Source: E-views 10.0 Output Data, 2020.

As shown in the table, the p-values of 0.0295 and 0.4144 indicate a rejection of the first null hypothesis and an acceptance of the second null hypothesis. This implies that CIC does Granger cause NGDP. However, NGDP does not Granger cause CIC. The p-value of the first hypothesis obtained is 0.0295 . This value is less than 0.05 , leading to a rejection of the null hypothesis and the acceptance of the alternate hypothesis. Currency in circulation does have an effect on economic growth in Nigeria.

\section{Granger Causality Results for NGDP and COB}

Pairwise Granger Causality Tests

Date: 03/12/20 Time: 09:41

Sample: 19922018

Lags: 3

\begin{tabular}{lccc}
\hline \hline Null Hypothesis: & Obs & F-Statistic & Prob. \\
\hline \hline COB does not Granger Cause NGDP & 24 & 0.68135 & 0.5755 \\
NGDP does not Granger Cause COB & & 4.73024 & 0.0141 \\
\hline \hline
\end{tabular}

Source: E-views 10.0 Output Data, 2020.

As shown in table above, the p-values of 0.5755 and 0.0141 indicate an acceptance of the first null hypothesis and a rejection of the second null hypothesis. This implies that COB does not Granger cause NGDP rather NGDP Granger causes COB. The p-value of 0.5755 is greater than 0.05 . This supports the acceptance of the null hypothesis. Therefore, currency outside banking has no effect on economic growth in Nigeria.

\section{Granger Causality Results for NGDP and CPS}

Paîrwise Granger Causality Tests

Date: 03/12/20 Time:08:42

Sample: 19922018

Lags: 3

\begin{tabular}{lcrr}
\hline \hline Null Hypothesis: & Obs & F-Statistic & Prob. \\
\hline \hline CPS does not Granger Cause NGDP & 24 & 2.12713 & 0.1345 \\
NGDP does not Granger Cause CPS & & 14.2171 & $7 . \mathrm{E}-05$ \\
\hline \hline
\end{tabular}

Source: E-views 10.0 Output Data, 2020.
As shown in the table, the p-values of 0.1345 and 0.00007 indicate an acceptance of the first null hypothesis and a rejection of the second null hypothesis. This implies that CPS does not Granger cause NGDP rather NGDP Grander causes CPS, then there is a unidirectional causal effect flowing from NGDP to CPS. The p-value of 0.1345 is greater than 0.05 . The null hypothesis is therefore accepted. By implication, credit to private sector has no effect on economic growth in Nigeria.

\section{Granger Causality Results for NGDP and RBD}

Pāirwise Granger Causality Tests

Date: 03/12/20 Time:08:46

Sample: 19922018

Lags: 3

\begin{tabular}{lccc}
\hline \hline Null Hypothesis: & Obs & F-Statistic & Prob. \\
\hline \hline RBD does not Granger Cause NGDP & 24 & 4.47932 & 0.0172 \\
NGDP does not Granger Cause RBD & & 6.57244 & 0.0038 \\
\hline \hline
\end{tabular}

Source: E-views 10.0 Output Data, 2020.

The p-values shown in table above are 0.0172 and 0.0038 which indicates a rejection of the first and second null hypotheses. This implies that RBD Granger causes NGDP and vice-versa. Therefore, there is a bi-directional causal effect between RBD and NGDP. The p-value of the first hypothesis obtained from table 4.9 is 0.0172 . The decision rule supports the rejection of the null hypothesis and the acceptance of the alternate hypothesis. Deposits of rural branches of commercial banks have an effect on economic growth in Nigeria.

Granger Causality Results for NGDP and RBL

Pāirwise Granger Causality Tests

Date:03/12/20 Time:08:49

Sample: 19922018

Lags: 3

\begin{tabular}{lrrr}
\hline \hline Null Hypothesis: & Obs & F-Statistic & Prob. \\
\hline \hline RBL does not Granger Cause NGDP & 24 & 6.29458 & 0.0045 \\
NGDP does not Granger Cause RBL & & 5.45599 & 0.0082 \\
\hline \hline
\end{tabular}

Source: E-views 10.0 Output Data, 2020.

The p-values shown in the table are 0.0045 and 0.0082 which indicates a rejection of the first and second null hypotheses. This implies that RBL Granger causes NGDP and vice-versa. Therefore, there is a bi-directional causal effect between RBL and NGDP. The p-value of the first hypothesis obtained is 0.0045 . This value is less than 0.05 , leading to a rejection of the null hypothesis and the acceptance of the alternate hypothesis. Loans of rural branches of commercial banks have an effect on economic growth in Nigeria. 
Granger Causality Results for NGDP and MFBD

Pāirwise Granger Causality Tests

Date: 03/12/20 Time:08:45

Sample: 19922018

Lags: 3

\begin{tabular}{lcrr}
\hline \hline Null Hypothesis: & Obs & F-Statistic & Prob. \\
\hline \hline MFBD does not Granger Cause NGDP & 24 & 1.89064 & 0.1695 \\
NGDP does not Granger Cause MFBD & & 2.58168 & 0.0873 \\
\hline \hline
\end{tabular}

Source: E-views 10.0 Output Data, 2020.

The p-values shown in table above are 0.1695 and 0.0873 which indicate an acceptance both the first and second null hypotheses. This implies that MFBD does not Granger cause NGDP and NGDP does not Granger cause MFBD, then there is no causal effect between MFBD and NGDP. The p-value obtained from the table is 0.1695 which is greater than 0.05 , therefore the null hypothesis is accepted. Microfinance banks' deposits have no effect on economic growth in Nigeria.

\section{DISCUSSION OF THE FINDINGS}

The main aim of the study is to examine the effect of financial inclusion on economic growth in Nigeria. The study therefore examined the effects of number of commercial banks' branches, currency in circulation, currency outside banks, microfinance banks' deposit, commercial banks' credit to private sector, loans and deposits of rural branches of commercial banks on economic growth in Nigeria. The OLS regression method and the Granger causality tests were used to elaborately analyze the data. The findings of the study revealed that the number of commercial bank branches has negative insignificant relationship with economic growth, but it was also found to have no effect on economic growth in Nigeria. This finding is against the priori expectation of the researcher. The finding also negates the findings of Onaolapo (2015) who found that the number of commercial bank branches contributes positively to the Nigerian economy using non-stationary data. Similarly, currency outside banking was found to have positive and insignificant relationship with economic growth in Nigeria. Also, currency outside banking had no effect on economic growth rather economic growth affected it. This suggests that as the economy of Nigeria grows, there is likely to be more and more currency outside the banking sector. On the other hand, currency in circulation has positive and insignificant relationship with economic growth. It was also found to have an effect on economic growth.

Commercial banks' credit to private sector had positive insignificant relationship on economic growth. However, the causal effect found between both variables flowed from economic growth to commercial banks' credit to private sector. This suggests that as the Nigerian economy grows, the rate at which the commercial banks grant loans to private sector will also increase. This explains the positive relationship. Levine, Loayza \& Beck (2000) also found positive link between private credit and economic growth in their study.

The loans granted by rural branches of commercial banks are also found to have positive and significant relationship with economic growth and a bi-directional causal effect on economic growth. In other words, the loans granted by branches of commercial banks have caused a development in the Nigerian economy which in turn has led to further granting of loans by the rural branches of commercial banks. The finding correlates with the finding of Onaolapo (2015) who found that loans issued to rural areas help increase the per capita income in Nigeria. Similarly, the deposits of rural branches of commercial banks were also found to have positive but insignificant relationship with economic growth in Nigeria. Likewise, a bi-directional relationship was found between both variables suggesting that improvement in economic growth is attributable to the increase in deposits accumulated in the rural areas. This improvement in turn leads to further increase in the deposit of rural branches of commercial banks in Nigeria.

The findings of the study also revealed that microfinance banks' deposits had negative and insignificant relationship with economic growth. The findings also revealed that microfinance banks' deposits had no effect on the economic growth of Nigeria. The F-statistic shows that generally financial inclusion insignificantly predicts economic growth. However, positive relationships found in majority of the variables show that financial inclusion contributes positively to economic growth. This correlates with the findings of Swamy (2012) who found that bank-led financial inclusion has definite advantages for economic growth. Yorulmaz (2016) also found that financial inclusion index also contributes positively to GDP per capita. Onwioduokit (2007) also found evidence of causal relationship going from financial sector variables to economic growth in Nigeria.

\section{CONCLUSION}

Based on the findings of the study, the researcher therefore comes to conclusions that provision of banking services in the rural areas will contribute positively to the economic growth in Nigeria. Such services mainly including accepting deposits and granting loans. The researcher also concludes that has not affected economic growth in Nigeria the way it ought to; showing lapses in the allocation of credit to private sector in Nigeria. Currency in circulation, one part of the narrow money supply, has positively affected Nigeria's economic growth. The flow of currency through banking transactions has actually promoted economic activities and has led to improvement in the Nigerian economic development. However, currency outside banks which is the other component of narrow money supply has no effect on economic growth. Surprising, commercial bank branches have also had a negative relationship on economic growth though not significantly. The insignificance of financial inclusion on economic growth in Nigeria has been established by this study 
and this raises calls examine the contributions of the financially excluded to economic growth.

\section{RECOMMENDATIONS}

Having drawn conclusion from the findings of the study, the researcher therefore makes the following recommendations.

In setting monetary targets, the monetary authorities must adopt policies that ensures that a large majority of the narrow money supply $\left(\mathrm{M}_{1}\right)$ is made up of currency in circulation; thereby reducing the amount of money outside banks. The rural bank branches should be encouraged to grant loans to private businesses and small scale enterprises so as to further promote economic growth.

Rural bank branches should be enabled to provide incentives to depositors and savers. So as to encourage deposits and positively improve economic growth. Banks are encouraged to maintain their commitment to sustainability in designing their business models to enable them to cope with disruptions and make a positive environmental and social impact in their quest to deliver value to their stakeholders. Banks and other financial institutions can only survive disruptive events if they fully embrace sustainability principles stressing that this had become even more critical during periods of significant disruptions such as the coronavirus pandemic (COVID-19) ravaging the world.

Though primarily a health crisis, the negative spillover effects on business and the economy are complex and pervasive, considerably slowing economic activities in most countries. Before the disruption caused by COVID-19 pandemic, financial services was undergoing significant evolution. Banks have had to modify their business models to address changes caused by innovation, digitalization, new entrants by Fintechs, increasing regulation and changing needs and behavioural patterns of customers

The government and monetary authorities should ensure the promotion of banking service and the establishment of bank branches deeper in the rural areas and equally support these banks to meet the demands of these areas efficiently.

\section{REFERENCES}

[1] Abbas, U. I. \& Atanda, O. O. (2019). An Analysis of Financial Inclusion in Nigerian Banks: From the Prospects and Challenges Perspective. The International Journal of Business \& Management 7(6)

[2] Aina, S. \& Oluyombo, O. (2014). The Economy of Financial Inclusion in Nigeria: Theory, Practice and Policy, Chatered Institute of Bankers of Nigeria Occasional Papers Series 1(1), 132.

[3] Akhil D. (2016). Financial Inclusion: Issues and Challenges, International of Technology 4(2)

[4] Anyanwu, F. A., Ananwude, A. C. \& Nnoje, A.I. (2018). Financial Inclusion: Nigeria's Microfinance Model Effect Assessment On Women Empowerment, European Journal of Human Resource Management Studies 1(2)

[5] El Said, A., Emara, N. \& Pearlman, J. (2020). On the Impact of Financial Inclusion on Financial Stability and Inequality: The Role of Macroprudential Policies (20/06). London, UK: Department of Economics, City, University of London.
[6] Eton, M., Uwonda, G., Mwosi, F., Barigye, G., \& Ogwel, P.B. (2019). Financial Inclusion and Economic Growth in Uganda A case study of selected districts in Western Uganda. International Journal of Advances in Scientific Research and Engineering 5(10)

[7] Gazdar, K. \& Cherif, K. (2014). The Quality of Institutions and Financial Development in Mena Countries: An Empirical Investigation Risk governance \& control: financial markets \& institutions4 (4) 65-80

[8] National Financial Inclusion Strategy, Central Bank of Nigeria 2018

[9] Kama, U. \& Adigun, M. (2013). Financial Inclusion in Nigeria: Issues and Challenges, Occasional Paper no.45

[10] Kazeem, B. A. (2017). Determinants of Financial Inclusion in SubSaharan Africa Countries: Does Institutional Infrastructure Matter? CBN Journal of Applied Statistics,. 8 (2) 69 -89

[11] Levine, R., Loayza, N. \& Beck, T. (2000). Financial inclusion and growth: Causality and causes. Journal of Monetary Economics, 46, 31-77

[12] Nalini, G. S. and Mariappan, K. M. (2012) Role of Banks in Financial Inclusion. Research Journal of Commerce \& Behavioural Science, 1 (4), 33-36

[13] Nwafor, M. C. \& Yomi, A. I. (2018). The Nexus between Financial Inclusion and Economic Growth: Evidence from Nigeria, International Journal of Research and Innovation in Social Science (IJRISS) 2(4).

[14] Nwanna, I.O and Chinwudu, F.C. (2016) “ The effect of Financial Deepening on Economic Growth in Nigeria (19852014)" IOSR Journal of Economics and Finance (IOSR-JEF), 7( 4) Ver.1 11-28 DOI: 10.9790/5933-0704011128 www.iosrjornals.org

[15] Nwanna, I.O and John, E.I. (2016) " Banking Reforms and the Effect on Economic Development in Nigeria "IOSR Journal of Humanities and Social Sciences (IOSR-JHSS), 21 (7) Ver.3 64-71 DOI: 10.9790/0837-2107036471 www.iosrjornals.org

[16] Nguling'wa, P. B. (2019). The Impact of Financial Inclusion on Economic Growth In Sub-Saharan Africa Journal of Applied Economics and Business 7(4), 51-68

[17] Mbutor O. M. \& Uba, I. A. (2013). The impact of financial inclusion on monetary policy in Nigeria. Journal of Econmomics and International Finance 5(8), 318-326

[18] Olubanjo, M.A. (2017). The Drivers of Financial Inclusion in Nigeria. The International Journal of Business \& Management. 273, 5 (7) July, 2017

[19] Omojolaibi, J. (2017). Financial Inclusion, Governance and Economic Progress In Nigeria: What Happens To The Welfare of the Poor? Arabian Journal of Business and Management Review $6,(7), 72-85$

[20] Onaolapo, A. (2015). Effects of financial inclusion on the economic growth of Nigeria. International journal of Business and Management Review, 3(8), 11-28.

[21] Onwiduokit, E. (2007). Financial sector development and economic growth: The Nigerian experience. West African Journal of Monetary and Economic Integration, 7(1), 14-32

[22] Swammy, V. (2012). Bank-based financial intermediation for financial inclusion and inclusive growth. In Balele N. (2019). The impact of financial inclusion on economic growth in sub-Saharan Africa. Journal of Applied economics, 7(4), 51-68.

[23] Wokabi, V. W. \& Fatoki, O. I. (2019). Determinants of Financial Inclusion In East Africa. International Journal of Business and Management, Vol. VII(1), pp. 113-131.,

[24] Yorulmaz, R. (2016). Construction of a financial inclusion index for the member and candidate countries of the European Union. Sayistay Dergisi, 102

[25] Zulkhibri, M. \& Ghazal, R. (2017). The Impacts of Governance and Institution on Financial Inclusion: Evidence from Muslim Countries and Developing Economies JKAU: Islamic Econ, 30, $37-60$ 